\title{
Categories of mining areas of closed mines due to limitations of land use for building purposes on selected examples
}

\author{
Piotr Strzałkowski ${ }^{1}$, Roman Ścigatal and Katarzyna Szafulera ${ }^{1, *}$ \\ ${ }^{1}$ Silesian University of Technology, Faculty of Mining and Geology, 2 Akademicka Street, 44-100 \\ Gliwice, Poland
}

\begin{abstract}
The paper presents the issue of categorization of mining areas of liquidated coal mines in terms of land development limitations. The authors have presented their observations regarding the determination of hazard zones resulting from the presence of linear and surface discontinuous deformations, excessive subsidence and tilt zones as well as the duration of the final phase of deformation process.
\end{abstract}

Keywords: mine closure, mining area protection, post-mining deformations

\section{Introduction}

The environmental impact of mining exploitation encompasses a wide spectrum of factors, occurring both: during the exploitation as well as after the completion of mining works or liquidation of the mine. Based on the experience described broadly in professional literature, a special hazard to structures on the surface is caused by shallow extraction fields and roadways including development headings (shafts, ore passes, dip headings and boreholes). These workings, especially the ones from the times in which the liquidation was not properly conducted, pose a potential hazard of discontinuous surface deformations. Oftentimes, the lack of full geological and mining documentation regarding the location of the headings and their way of liquidation constitutes another adverse condition. Also discontinuous linear deformations cause a considerable hazard to the surface. Such deformations are related to existence of overlapping multiple exploitation edges in several mined out coal seams and the presence of fault zones.

This paper takes up the issues of determining the limits of hazard zones occurring due to the possibility of discontinuous surface deformations and linear deformations, as well as zones of excessive subsidence, tilt and the related changes of hydrological conditions and the duration of the final phase of deformations. The limits are determined to specify the categories of the mining areas of liquidated mines pertaining to land use limitations.

* Corresponding author: katarzyna.szafulera@polsl.pl 


\section{Qualification of liquidated mine areas for development and rehabilitation}

As provided in [1], liquidated mining areas are classified into categories of mining areas based on the limitations for land use purposes. These categories are determined based on the post-exploitation transformation level, which serves for the specification of the hazard level and the resulting fitness of the area for construction. The choice of an adequate category for area being classified requires expert knowledge and experience, the analysis of geological and mining conditions as well as conducting specialized tests. In Poland, according to [1], the following categories are distinguished :

- A - post-mining terrain fit for development.

- $\quad$ B - post-mining terrain conditionally fit for development. Sub-categories are included here: $\mathbf{B}_{1}, \mathbf{B}_{\mathbf{2 1}}, \mathbf{B}_{\mathbf{2 2}}, \mathbf{B}_{\mathbf{2 3}}$.

- $\quad \mathbf{C}$ - post-mining terrain unfit for construction purposes - high risk of mining damages.

Due to limited volume of this paper we do not present the complete classification table, which can be found in the work [1].

\section{Assessment of fitness of an area for construction based on analysis of continuous deformations caused by conducted mining exploitation}

In line with the binding provisions, entities conducting mining operations are obliged to present within the operating plan of a liquidated mine, the maps of isolines of total subsidence and tilt caused by the mining exploitation throughout the entire period of operation. Such documentation allows to determine the areas of excessive change in terrain morphology and related changes in hydrological conditions as well as the possibility of formation of isolated basins, flooding areas and drying zones.

The situation is very similar in case of determination the categories of mining area after mine closure. The important difference is however, that such categories are determined first of all on the basis of the extreme horizontal strain resulting from performed exploitation. Important problem arises in this case - horizontal strain can not simply be summed up throughout the entire period of mine operation, as it is carried out for subsidence or tilt. In case of horizontal strain, often the so-called "strain relaxation" phenomena is considered to be used in calculations $[2,3,4]$ or values pertaining to 10 -year periods of mining operations are taken into account in their summation [5].

Another issue which influences the results of the assessment of the land usability of a liquidated mine area is the determination of the duration of the final phase of the deformation process. According to the guidelines presented in [6], the time necessary for mining-induced subsidence to be finished, amounts approximately to 5 years. After that time, the mining area of a closed mine may be re-classified from category $\mathbf{B}_{\mathbf{1}}$ to category $\mathbf{A}$, under the condition, that no other hazards are present. Despite these guidelines, in some cases there is the necessity to precisely determine the time, when the effects of the mining exploitation conducted in the area of the liquidated mine shall cease.

According to $[6,7]$, the duration of the final phase of the deformation process depends on the depth of exploitation, the mechanical properties of rock mass, the roof control method and the rate of extraction front advance. It may be determined based on the measured changes of subsidence over time or based on the empirical formulas corresponding to the given mining and geological conditions. One of such solutions is the equation presented in [7]: 


$$
T=0.028 \frac{H}{(\operatorname{tg} \beta)^{0.5}}
$$

where:

$\mathrm{T}$ - the time necessary for finishing of post-mining deformation process, [months]

$\mathrm{H}$ - the depth of exploitation, [m]

$\operatorname{tg} \beta$ - parameter of Budryk-Knothe theory describing exploitation influence range, $\left[{ }^{\circ}\right]$.

\section{Identification of areas of shallow mining exploitation and sinkhole hazard zones in the vicinity of surface-connected headings}

One of the key issues in classification of post-mining area due to the limitations in its use for land development purposes is the threat level assessment of discontinuous deformations arising. The presence of shallow workings as well as the presence of surfaceconnected headings is decisive for the level of post-exploitation transformation and determines the level of discontinuous deformations hazard.

\subsection{Identification of hazard zones caused by shallow mining exploitation}

To determine the zones of discontinuous surface deformations hazards, the maps of seams should be analysed in order to identify the areas of performed in the past shallow exploitation and the presence of shallow headings. This is because they are the basic factors that may cause sinkholes creation at the surface. Based on the practical experience and the results of the conducted research, the limit depth of hazard caused by shallow headings should be assumed to be of approx. $\mathrm{H}=100 \mathrm{~m}[8,9]$. Considering a safety margin, however, this depth is often increased to approximately $150 \mathrm{~m}$. It is evident that the sinkhole hazard decreases along with the depth and this is why it is proposed to grade the hazard based on this factor. Moreover, the classification of areas to each of the categories is decided by the presence and the dimensions of the sinkholes already formed in a given area. Based on the above, it is proposed to grade the hazard and to distinguish the following zones:

- The $\mathbf{B}_{23}$ category zone, encompassing areas in which the exploitation was conducted at a depth up to approx. $50 \mathrm{~m}$,

- The $\mathbf{B}_{22}$ category zone, encompassing areas in which the exploitation was conducted at depth range from 50 to $150 \mathrm{~m}$.

\subsection{Identification of hazard zones based on the presence of surface- connected workings}

The occurrence of sinkholes in the Upper Silesian Coal Basin is also associated with excavations having a connection to the surface. These are mainly exploratory and reconnaissance galleries, and above all, designed for deposit access. Very often these are historical underground objects, inaccessible today, and their liquidation method is usually unknown.

So, sinkholes in the areas of abandoned mines may arise on the surface as an effect of loss of stability of improperly liquidated shafts, ore passes, bootleg mines, adits, dip headings or even boreholes. The probability of shaft support degradation increases with time, due to physical and chemical processes occurring inside the rock mass, despite the closing and sealing of the shaft collar with a concrete slab. In case of backfilled shaft, there is also the possibility of void formation due to the migration of the material used for filling. 
As a result, the area in the direct vicinity of the shaft may be subject to subsidence, and a sinkhole may rapidly form in an extreme scenario.

Keeping in mind all above mentioned threats, the sinkhole formation hazard should be determined for surface-connected workings, that is, shafts, ore passes and headings.

The possible diameter of sinkhole is one of the significant parameters characterizing the hazard level. As provided in $[10,11]$, the calculated possible maximal diameter D of a sinkhole may be used for the determination of the protection zone around shafts and ore passes in the area of which a sinkhole may be formed. The diameter may be established based on Bell's solution, described with the equation (2). Fig. 1 presents an exemplary formation of sinkhole in an area of liquidated ventilation shaft.

$$
D=2 \cdot Z \cdot \operatorname{tg}\left(90^{\circ}-\varphi\right)+2 r
$$

where:

$\mathrm{h}$ - the thickness of the loose overburden,

$\varphi$ - the mean value of internal friction angle of the loose overburden material,

$r-$ the radius of the shaft.

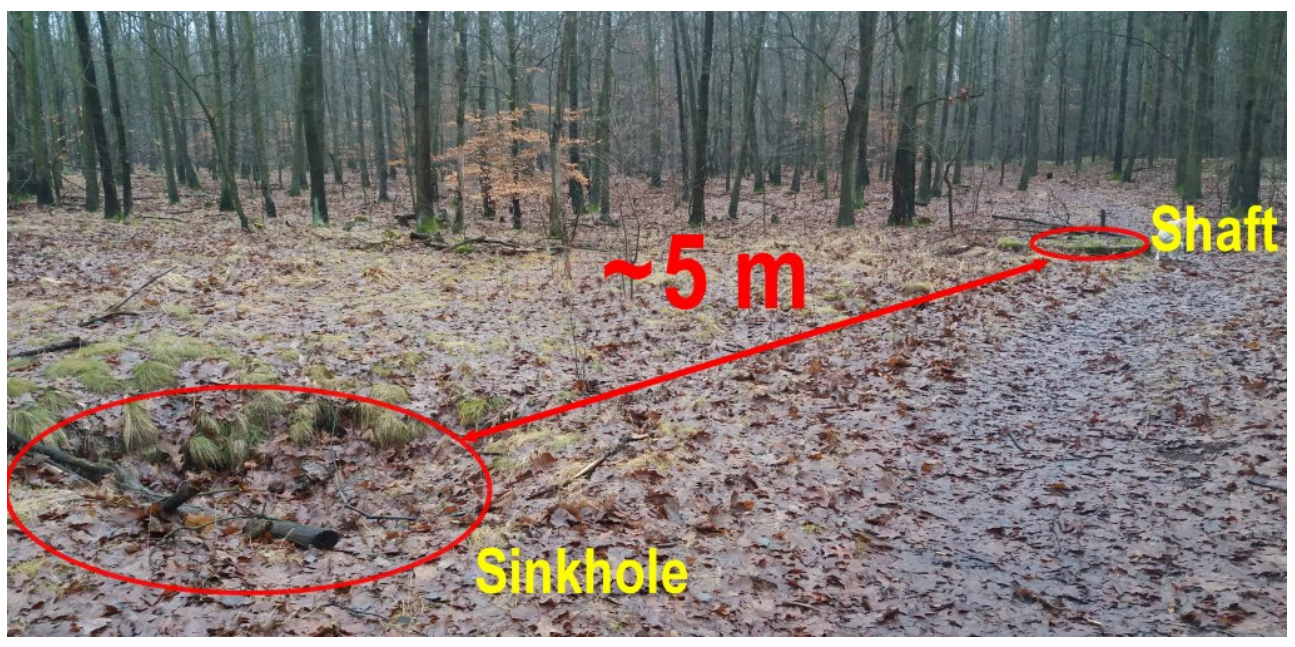

Fig.1. Example of a sinkhole in an area of a ventilation shaft.

Taking into account guidelines highlighted in [1] and the risk analysis combined with an adequate margin of safety, it is therefore proposed to establish the following zones:

- a C category zone - established around the locations of shafts; the width of the zone should be equal to three diameters of the shafts,

- a B $\mathbf{B}_{23}$ category zone - established around the locations of the shafts; the width of the zone shall be calculated based on the formula (2) for the maximal diameter of the sinkhole,

- a $\mathbf{B}_{22}$ category zone - constituted by an area of an additional $40 \mathrm{~m}$ wide safety strip.

According to the guidelines of documenting geological and engineering conditions for the purposes of mine closure [1], the classification of mining area based on the limitations in use for development purposes does not directly encompass boreholes. Considering, however, that the boreholes were mostly drilled in the beginning of the $19^{\text {th }}$ century, their diameters are smaller than $0.5 \mathrm{~m}$ and were lined with steel tubes only at the length of the loose overburden, it has been assumed that a large number of the boreholes became compressed. The self-liquidation process does not, however, concern all the boreholes, and 
a part of those still exist and cause a sinkhole hazard due to scouring and other non-mining phenomena. Due to the above, the authors of this paper propose that a $\mathbf{C}$ category zone should be established around each of the boreholes. The width of the zone should be $5 \mathrm{~m}$. At the same time, the possibility of placing a foundation of an object directly on a borehole has been excluded. The width of $\mathbf{B}_{23}$ category zone has been established based on formula (2), assuming the lowest thickness of the loose overburden in the analyzed area.

\section{Determination of discontinuous deformation hazard zones in the area of multiple extraction edges and fault zones}

Based on the rules of documentation of geological and engineering conditions for mine liquidation purposes [1] and the classification of mining area based on the limitations in use for development purposes, linear discontinuous deformation hazard zones should be established.

These zones should be determined based on expert knowledge and experience as well as based on analyses of causes of the occurrence of linear discontinuous deformations at the mining area. The zones exposed to the hazard of linear discontinuous deformations should most of all be established for areas of overlapping edges of exploitation areas and areas of tectonic disturbances (especially fault outcrops).

\subsection{Determination of hazard zones due to overlapping extraction edges}

For the purposes of determination of zones subject to linear discontinuous deformations in areas of edges of exploitation, it may be assumed that further discontinuous linear deformations may occur in areas in which they have been identified before and the cause of the occurrence thereof were the edges of exploitation. Additionally, in case of a liquidated mine, one should note that these shall be solely the areas subject to the effect of mining exploitation conducted by neighbouring mines. This way, the areas in the vicinity of the boundaries of the mining areas of the neighbouring mines will be identified. It is proposed that such areas should be classified into the $\mathbf{B}_{\mathbf{2 3}}$ category. The remaining areas of linear discontinuous deformations in the area of the overlapping exploitation edges have not been classified into this category. Such assumption was made due to the fact that the probability of activation of formerly identified discontinuous deformations without a direct impact of planned mining exploitation and other factors related to mining operations is rather low.

While establishing discontinuous linear deformation hazard zones resulting from the overlapping exploitation edges, it has also been decided to increase the safety margin around each of the zones by establishing a $40 \mathrm{~m}$ wide protective strip, classified into the $\mathbf{B}_{22}$ category.

\subsection{Establishment of hazard zones due to outcrops of tectonic faults on the roof of carboniferous formations}

For the purposes of determination of hazard zones due to linear discontinuous deformations in areas of tectonic disturbances [12,13], it may be assumed that the hazard is caused by the faults with a throw equal to or larger than $15 \mathrm{~m}$ and accompanied by fault zones with higher throws. It is proposed to assume that the hazard zone should be established at both sides of the outcrop of such a fault and the width thereof should be calculated by means of the equation [8]:

$$
D=1,2 \cdot h_{n} \operatorname{ctg} \alpha \text {, }
$$


where:

$\mathrm{h}_{\mathrm{n}}$ - the thickness of loose overburden layers, [m],

$\alpha$ - the angle of repose for loose overburden, $\left[^{\circ}\right]$.

The varying thickness of the overburden in the area of the deformations should be taken into account in the calculations. This will make it possible to study the relations between the location of the fault outcrop and the location of the identified deformations. Also the fact that the activity of the fault zones is definitely influenced by the conducted in the past mining exploitation (especially intensive exploitation) should be taken into account. Moreover, the suffosion phenomenon can not be excluded in the area of fault outcrops. The phenomenon may have an impact on the possibility of formation of linear deformations or in favourable conditions - surface-type deformations. Thus, deformations in the areas of outcrops may occur due to simultaneous occurrence of several factors.

For the purposes of mining area categorization according to the limitations for land development, it is proposed to introduce a sub-classification of the zones at both sides of the fault according to the variable hazard levels. The division can be made based on the number of deformations identified in the past. The zone directly in the area of deformations may be classified as $\mathbf{B}_{22}$ category. The zone in which discontinuous deformations have not been identified in the past may be classifies as $\mathbf{B}_{21}$ category.

\section{Guidelines regarding the development of post-mining areas}

Based on the work [1], as well as the knowledge and experience of the authors, it is proposed to develop general guidelines and instructions regarding the spatial planning for all liquidated mining areas.

Table 3. General guidelines and instructions regarding the spatial planning of liquidated mine areas.

\begin{tabular}{|c|c|l|}
\hline CATEGORY & $\begin{array}{c}\text { Post-exploitation } \\
\text { hazards }\end{array}$ & \multicolumn{1}{c|}{ Spatial planning guidelines } \\
\hline $\begin{array}{c}\text { A-fit for } \\
\text { development }\end{array}$ & None & \multicolumn{1}{c|}{ None } \\
\hline $\begin{array}{c}\text { B }_{1}- \\
\text { fonditionally } \\
\text { fit for } \\
\text { development }\end{array}$ & $\begin{array}{c}\text { Post-mining areas } \\
\text { in which the effects } \\
\text { of finished } \\
\text { exploitation may } \\
\text { occur }\end{array}$ & $\begin{array}{l}\text { Required opinion of a geologist holding SMA's authorisation. } \\
\text { The area may be classified as A category after 5 years from } \\
\text { completing the exploitation. }\end{array}$ \\
\hline & $\begin{array}{l}\text { Analysis of geological and mining archives and other source } \\
\text { materials. Required geophysical tests aimed at the assessment of } \\
\text { the rock mass condition. If the performance of works aimed at } \\
\text { the treatment of the rock mass is necessary, the tests should be } \\
\text { conducted prior to and after the performance of the treatment } \\
\text { works. The tests should be conducted with a method with a } \\
\text { depth range up to several dozen meters, depending on the depth } \\
\text { of the exploitation causing the discontinuous deformations } \\
\text { hazard. In case of formerly identified fissures and ground steps, } \\
\text { the range should reach at least several meters below the depth of } \\
\text { the object's foundation (high-resolution tests). }\end{array}$ \\
\hline
\end{tabular}


Table 3 cont. General guidelines and instructions regarding the spatial planning of liquidated mine areas.

\begin{tabular}{|c|c|c|c|}
\hline 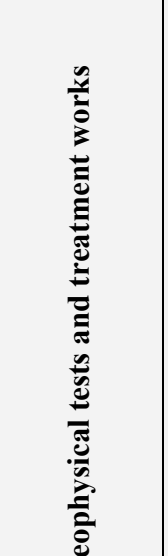 & & $\begin{array}{l}\text { - shallow mining } \\
\text { exploitation } \\
\text { - outcrops of } \\
\text { tectonic faults on } \\
\text { the roof of } \\
\text { carboniferous } \\
\text { formations } \\
\text { - shafts, ore passes }\end{array}$ & $\begin{array}{l}\text { Analysis of geological and mining archives and other source } \\
\text { materials. Required geophysical tests aimed at the assessment of } \\
\text { the rock mass condition. The tests should be conducted before } \\
\text { and after the treatment works (liquidation of voids in the rock } \\
\text { mass - gravitational injection - and/or fracture and loosening } \\
\text { zones - pressurized injection). The voids should be identified by } \\
\text { means of boreholes. The geophysical tests should be conducted } \\
\text { with at least two methods with a depth range up to several dozen } \\
\text { meters, depending on the depth of the exploitation causing the } \\
\text { discontinuous deformations hazard. In case of formerly } \\
\text { identified fissures and ground steps, the range should reach at } \\
\text { least several meters below the depth of the object's foundation } \\
\text { (high-resolution tests). } \\
\text { It is advised to conduct laboratory tests of physical and chemical } \\
\text { properties and gas properties, including sampling of air. }\end{array}$ \\
\hline 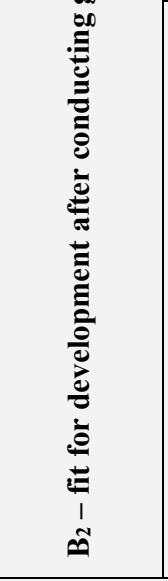 & & $\begin{array}{l}\text { - shallow mining } \\
\text { exploitation } \\
\text { - overlapping } \\
\text { exploitation edges } \\
\text { - outcrops of } \\
\text { carboniferous } \\
\text { sandstones } \\
\text { - shafts, ore passes } \\
\text { - boreholes }\end{array}$ & $\begin{array}{l}\text { Detailed analysis of geological and mining archives and other } \\
\text { source materials. Geophysical tests aimed at the assessment of } \\
\text { the rock mass condition should be conducted before and after the } \\
\text { treatment works (liquidation of voids in the rock mass - } \\
\text { gravitational injection - and/or fracture and loosening zones - } \\
\text { pressurized injection). The voids should be confirmed by means } \\
\text { of boreholes. The geophysical tests should be conducted with at } \\
\text { least two methods. It shall be required for the geophysical tests } \\
\text { to be of high resolution and depth range reaching up to over a } \\
\text { dozen meters and a lower resolution up to several dozen meters, } \\
\text { depending on the depth of the cause of the discontinuous } \\
\text { deformation hazard. It is also advised to conduct laboratory tests: } \\
\text { of physical and mechanical properties, hydrogeological } \\
\text { properties and gas tests including: the filtration coefficient tests, } \\
\text { observation of the water table level variations and sampling of } \\
\text { water and air. }\end{array}$ \\
\hline $\begin{array}{l}C-\text { unfit } \\
\text { constructi }\end{array}$ & & $\begin{array}{l}\text { - shafts, ore passes } \\
\text { - boreholes } \\
\text { - flooding }\end{array}$ & $\begin{array}{l}\text { Not applicable. It is advised to exclude the development of the } \\
\text { area and to use the area in purposes other than construction, e.g. } \\
\text { green areas, recreation areas, parks, etc. }\end{array}$ \\
\hline
\end{tabular}

\section{Summary}

The guidelines [1] regarding land development planning in areas of liquidated mines encompassing construction need the safety requirements to be fulfilled first. A correct assessment of the suitability of an area for development requires terrain categorization resulting from the analyzes of changes of the geological and engineering conditions caused by mining exploitation.

The categories of mining areas of liquidated mines in the Upper-Silesian Coal Basin according to the limitations for use for construction purposes should be established based on the recognition of: shallow mining exploitation, overlapping edges of exploitation areas, outcrops of tectonic faults, location of shafts, ore passes, boreholes, flooding areas, dumps and rehabilitated areas. The above constitute a basis for geological and engineering categorization and allow for a division of the areas of liquidated mines into areas fit for construction - "A category", areas conditionally fit for construction (after prior treatment) "B category" and areas unfit for construction - "C category". 
The treatment of post-mining areas is aimed at rendering these areas fit for possible construction. This requires remediation works which should be interpreted i.e. as a permanent protection of surface-connected workings, filling shallow voids from the surface, liquidation of fractured and loosened zones by injection, compacting or replacement of grounds, filling isolated basins with a fill material or the drainage thereof.

The above tasks require the performance of specialized geological, engineering and geophysical works. The works should be aimed at determination of the local conditions of the rock mass and the identification of mining hazards. The determination of the rock mass quality allows to establish the land use method and to develop technical plans of rehabilitation and redevelopment of post-mining areas.

\section{References}

1. Ministerstwo Środowiska: Zasady dokumentowania warunków geologiczno inżynierskich dla celów likwidacji kopalń. Warszawa (2009)

2. J Białek: Algorytmy i programy komputerowe do prognozowania deformacji terenu górniczego. Monografia. Wydawnictwo Politechniki Śląskiej. Gliwice (2003)

3. J Kwiatek: O reologicznych aspektach zagrożenia obiektów budowlanych na terenach górniczych. Prace Nauk. GIG nr 827. Katowice (1997)

4. P Strzałkowski, K Szafulera: Przykład analizy sumowania deformacji terenu górniczego w długim okresie czasu. Bezpieczeństwo Pracy i Ochrona Środowiska w Górnictwie, nr 10 (2016)

5. S Knothe: Prognozowanie wpływów eksploatacji górniczej. Wydawnictwo "Śląsk". Katowice (1984)

6. P Strzałkowski, R Ścigała: Determination of the duration of surface subsidence caused by underground extraction. Schriftenfreihe des Institutes fur Markscheidewewsen und Geodäsie an der Technischen Universitat Bergakademie Freiberg., str. 77-81 (2010)

7. M Chudek, P Strzałkowski, R Ścigała: Czas trwania poeksploatacyjnych deformacji powierzchni terenu w zależności od warunków geologiczno-górniczych. Budownictwo Górnicze i Tunelowe. Kwartalnik Naukowo-Techniczny nr 3, str. 38-42 (2000)

8. M Chudek, W Janusz, J Zych: Studium dotyczace rozpoznania tworzenia się i prognozowania deformacji nieciagłych pod wpływem podziemnej eksploatacji złóż (1988)

9. A Kowalski: Deformacje powierzchni w Górnośląsim Zagłębiu Węglowym. Główny Instytut Górnictwa, Katowice (2015)

10. F G Bell: Land development. State of the art in location of old mine shafts Bulletin of the Int. Association of Engineering Geology 37 (1988)

11. Z Pilecki: Zagrożenie deformacjami nieciagłymi na obszarze górniczym Jaworzno III. IGSMiE PAN. Kraków (2012)

12. A Kowalski: O liniowych nieciągłościach powierzchni. Bezpieczeństwo Pracy i Ochrona Środowiska w Górnictwie, nr 12 (2005)

13. P Strzałkowski, R Ścigała: The causes of mining induced ground steps occurrence - case study from Upper Silesia in Poland. Acta Geodyn. Geomater., 14, No. 3 (187), 305312, DOI: 10.13168/AGG.2017.0013 (2017) 